\title{
Prevalence of three cardinal risk factors in a random sample of men and in patients with ischaemic heart disease
}

\author{
T. B. S. Dick and M. C. Stone \\ From the Clinical Research Unit, Leigh Infirmary, Leigh, Lancs.
}

A I in 2 sample taken from a general practice of 2,800 was studied to ascertain the prevalence of hyperlipidaemia, hypertension, and smoking, all shown by prospective studies to be risk factors in coronary disease. $A$ lipoprotein analysis by membrane filtration and nephelometry was performed on all subjects. The male subjects of this sample from the age group 30 to 69 years have been compared with a group of patients with known ischaemic heart disease, matched for age and sex and investigated in an identical way. The prevalence of all three factors was greater in the ischaemic heart disease group but was statistically significant for hyperlipidaemia and smoking only. The prevalence of risk factors taken in isolation or in combination when uninfluenced by the factors is shown. The prevalence of the combination of hyperlipoproteinaemia and hypertension when they are uninfluenced by smoking shows no correlation with ischaemic heart disease. When smoking is added to either hypertension or hyperlipoproteinaemia there is a significant relation with ischaemic heart disease. Smoking appears to be an important factor for its additive or synergistic effect.

A coronary risk factor has been defined by the American Heart Association as 'a finding associated with at least doubling of the risk' (Stamler et al., 1969). Though the aetiology of coronary disease has not been precisely established, much work has been done on risk factors in prospective studies (Stamler et al., 1969; Dawber et al., I962; Doyle et al., 1959; Keys et al., 1963; Morris et al., I966; Tibblin, 1970), mainly in the U.S.A. It has been reported that retrospective prevalence studies show similar findings (Friedman et al., 1966; Medalie et al., 1968; Mulcahy, Hickey, and Maurer, 1969). Since the incidence of coronary heart disease varies between countries (American Heart Association, 1970), we have investigated the prevalence of hyperlipoproteinaemia, hypertension, and smoking, the 'cardinal' coronary risk factors (Stamler, 1971), in a random sample of subjects taken from one general practice, and have similarly investigated a group of patients with known ischaemic heart disease. Our results differ in certain respects from those previously reported, and have a bearing on the suggestion by Stamler et al. (1969) that the three 'cardinal' risk factors be controlled or removed as a preventive measure in advance of the result of prospective thera-

Received 25 September 1972. peutic trials. We feel it is pertinent to report our findings for the factors hyperlipoproteinaemia, diastolic hypertension, and smoking in the male groups 30 to 69 years.

\section{Subjects}

The subjects of this investigation were inhabitants of Leigh, an industrial town of 46,000 people with a hospital catchment of nearly 100,000. It is a relatively static population concerned mainly with the manufacture of cotton, artificial fibres, and electrical cable; in addition, there is some coal-mining, general engineering, and agriculture. There were two groups of subjects.

\section{a) Random sample of 283 men}

The random sample was a $I$ in 2 selection made by M.C.S. from his general practice records. It was confined to subjects over the age of 15 years and included 480 men and 534 women. This report is confined to the 283 men aged 30 to 69 years $(88 \%$ of 322 male subjects in this age group). They are referred to as the 'random sample'.

This group contained 26 subjects ( $9 \cdot 2 \%$ ) known to have ischaemic heart disease; 8 subjects $(2 \cdot 8 \%)$ found to have abnormal electrocardiograms classified as definite or probable ischaemic heart disease who were otherwise in good health (for the Minnesota coding of definite and probable coronary heart disease see later); and a further 4 subjects $(I \cdot 4 \%)$ had previously had severe 
chest pain likely to have been due to ischaemic heart disease but who had normal cardiograms when examined. Data from the random sample group reported in this paper include these 38 subjects.

\section{b) Ischaemic heart disease group of 146 men}

In this group we report on the comparable age group 30 to 69 for men. Two subcategories were myocardial infarction (I IO men) and angina pectoris (36 men). All had been admitted to Leigh Infirmary under the care of T.B.S.D. Only cases of myocardial infarction were included in this group, i.e. they had a typical history with a changing pattern in serial electrocardiograms (Group I and Group II changes - see later). No case without typical electrocardiographic abnormalities was included, but they were otherwise unselected.

In the cases of angina pectoris, each author took the history independently and only cases with a classical history on each occasion were included. No cases of postinfarction angina were included in this subgroup.

For the purpose of this survey, in every case of ischaemic heart disease we report on the investigations carried out not less than three months after the acute episode.

\section{Methods}

Subjects from all groups were investigated in an identical way.

I) History in relation to previous illness and smoking habits.

2) Examination of the heart and casual blood pressure by T.B.S.D. The casual blood pressure was taken in a private cubicle using a mercury sphygmomanometer with a $12.7 \mathrm{~cm}$ cuff, with the subject lying down. These readings were made to the nearest $5 \mathrm{~mm}$. The diastolic pressure was defined as that at which all sounds ceased; the first reading only in each subject was recorded.

3) A I2-lead electrocardiogram (Cambridge Instrument Co.) was taken, all tracings being coded according to the Minnesota code by T.B.S.D. (Blackburn et al., 1960).

4) Lipoprotein analysis: blood was drawn after a I4-hour overnight fast for the determination of the lipoprotein pattern. The concentrations of the lipoprotein fractions were estimated from the results of ' $M N C$ analysis' which comprises membrane filtration, nephelometry (light scattering photometry), and serum cholesterol estimation.
Serum total cholesterol was estimated by the method of Connerty, Brigg, and Eaton (196I). The accuracy and reproducibility of the method is described elsewhere (Stone et al., 1970).

Membrane filtration and nephelometry were carried out by the method of Stone et al. (I970).

The concentrations of the 3 lipoprotein fractions, $\mathrm{S}$ particles $\left(S_{\mathrm{f}}\right.$ 0-20, beta lipoproteins), $M$ particles $\left(S_{f}\right.$ 20-400, pre-beta lipoproteins), and $L$ particles $\left(S_{f}>400\right.$, chylomicrons), were calculated from the value of serum cholesterol and the nephelometric measurements, using equations described by Stone et al. (I97I), who have shown a high correlation between these estimated values and those obtained by analytical ultracentrifugation. The lipoprotein patterns were classified as 'normal' or 'abnormal', as described fully elsewhere (Stone et al., 1971). A 'significantly abnormal lipoprotein pattern' is one in which the concentrations of one or more of the lipoportein fractions exceed the following limits: 550 $\mathrm{mg} / \mathrm{ro0} \mathrm{ml}$ for S particles; $240 \mathrm{mg} / \mathrm{ro0} \mathrm{ml}$ for $\mathrm{M}$ particles; or $25 \mathrm{mg} / 100 \mathrm{ml}$ for $\mathrm{L}$ particles. In this paper the term 'hyperlipoproteinaemia', is synonymous with 'significantly abnormal lipoprotein pattern'.

As defined elsewhere (Stone et al., 1971), a significantly abnormal lipoprotein pattern can occur only if the serum cholesterol concentration exceeds $270 \mathrm{mg} / \mathrm{I} 00$ $\mathrm{ml}$, or the serum triglycerides exceed $200 \mathrm{mg} / \mathrm{ro0} \mathrm{ml}$, or if both these abnormalities are present.

5) Definition of ischaemic heart disease Definite ischaemic heart disease $=$ subject has classical history and electrocardiogram coded as I I, IV I, V I. Very probable ischaemic heart disease $=$ classical history with coding I 2, IV 2, V 2, VI I or 2, VII I or 2. Emphasis was laid on serial electrocardiograms and changing patterns.

6) Statistical analysis The significance of differences in prevalence given in Tables I to IV was estimated by calculation of $\chi^{2}$.

\section{Results}

\section{Total prevalence (Table I)}

The prevalence of 'significant' hyperlipoproteinaemia, smoking $\geqslant 15$ cigarettes a day, and diastolic blood pressure $\geqslant 95 \mathrm{mmHg}$ is shown in Table I

TABLE I Prevalence of risk factors in random sample and in patients with ischaemic heart disease

\begin{tabular}{|c|c|c|c|c|c|c|c|c|c|c|c|c|}
\hline \multirow[t]{3}{*}{ Risk factors } & \multicolumn{4}{|c|}{$30-39$ years } & \multicolumn{4}{|c|}{$40-49$ years } & \multicolumn{4}{|c|}{$50-59$ years } \\
\hline & \multicolumn{2}{|c|}{$\begin{array}{l}\text { Random } \\
\text { sample } \\
(N=6 I)\end{array}$} & \multicolumn{2}{|c|}{$\begin{array}{l}\text { Ischaemic } \\
\text { heart disease } \\
(N=I 0)\end{array}$} & \multicolumn{2}{|c|}{$\begin{array}{l}\text { Random } \\
\text { sample } \\
(N=84)\end{array}$} & \multicolumn{2}{|c|}{$\begin{array}{l}\text { Ischaemic } \\
\text { heart disease } \\
(N=5 I)\end{array}$} & \multicolumn{2}{|c|}{$\begin{array}{l}\text { Random } \\
\text { sample } \\
(N=82)\end{array}$} & \multicolumn{2}{|c|}{$\begin{array}{l}\text { Ischaemic } \\
\text { heart disease } \\
(N=55)\end{array}$} \\
\hline & No. & $\%$ & No. & $\%$ & No. & $\%$ & No. & $\%$ & No. & $\%$ & No. & $\%$ \\
\hline Hyperlipoproteinaemia & I I & $18 \cdot 0$ & 8 & $80 \cdot 0 \ddagger$ & 21 & $25 \cdot 0$ & 21 & $4 I \cdot 2$ & 14 & $16 \cdot 8$ & 22 & $40.0+$ \\
\hline Smoking $\geqslant 15 /$ day & 27 & $44 \cdot 3$ & 8 & $80 \cdot 0^{\circ}$ & 43 & $51 \cdot 2$ & 36 & $70 \cdot 6$ & 45 & $54 \cdot 2$ & 36 & $65 \cdot 5$ \\
\hline Diastolic BP $\geqslant 95 \mathrm{mmHg}$ & 8 & I3.I & 2 & $20 \cdot 0$ & 22 & $26 \cdot 2$ & 16 & $3 I \cdot 4$ & 25 & $30 \cdot 5$ & 22 & $40 \cdot 7$ \\
\hline
\end{tabular}

$\star P<0.05 . \quad+P<0.01 . \quad \neq P<0.001$. 
where the two groups 'random sample' and 'ischaemic heart disease' are compared in decades of age. In every decade ( 30 to 69 year age range) there is a greater prevalence of all three risk factors in the ischaemic heart disease group, except for hypertension in the 60 to 69 decade. Though this increase in prevalence is not always statistically significant, it is significant in the total 30 to 69 group both for hyperlipoproteinaemia $(\mathrm{P}<0.00 \mathrm{I})$ and smoking $(\mathrm{P}<0.05)$. There is a steady rise in the prevalence of hypertension with age in both groups until the age of 60; before that diastolic hypertension is more prevalent in every decade in the ischaemic heart disease group, but is not statistically significant at the 5 per cent level.

\section{Prevalence of each factor in absence of other two}

In Table 2 we show in age groups 30 to 49, 50 to 69, 30 to 69 the numbers and percentage prevalence for hyperlipoproteinaemia, smoking, and diastolic blood pressure where they occur alone as the only one of these three factors in these subjects. There is a significant increase of prevalence in the ischaemic heart disease group for hyperlipoproteinaemia only. If we separate each factor in this way, the numbers are inevitably small, too small in the main to permit the use of $\chi^{2}$ if the results are given in decades.

\section{Prevalence of two factors in absence of third (Table 3)}

In Table 3, two factors are combined in such a way that in each group the third factor is not present. In the 30 to 49 year group smoking combined with hyperlipoproteinaemia $(\mathbf{P}<0.01)$, and smoking with diastolic hypertension $(\mathrm{P}<0.05)$ both show a significant increase in prevalence in the ischaemic heart disease group. However, when hyperlipoproteinaemia and diastolic hypertension are present and smoking is absent the percentage prevalence is virtually the same for both samples in all age groups.

\begin{tabular}{|c|c|c|c|c|c|c|c|}
\hline \multicolumn{4}{|c|}{$60-69$ years } & \multicolumn{4}{|c|}{$30-69$ years } \\
\hline \multicolumn{2}{|c|}{$\begin{array}{l}\text { Random } \\
\text { sample } \\
(N=56)\end{array}$} & \multicolumn{2}{|c|}{$\begin{array}{l}\text { Ischaemic } \\
\text { heart disease } \\
(N=30)\end{array}$} & \multicolumn{2}{|c|}{$\begin{array}{l}\text { Random } \\
\text { sample } \\
(N=283)\end{array}$} & \multicolumn{2}{|c|}{$\begin{array}{l}\text { Ischaemic } \\
\text { heart disease } \\
(N=I 46)\end{array}$} \\
\hline No. & $\%$ & No. & $\%$ & No. & $\%$ & No. & $\%$ \\
\hline 9 & $16 \cdot I$ & 8 & $26 \cdot 7$ & 55 & $19 \cdot 4$ & 59 & $40 \cdot 47$ \\
\hline $2 I$ & 37.5 & I6 & 53.3 & 136 & $48 \cdot I$ & 96 & 65.8 \\
\hline 30 & $55 \cdot 6$ & 15 & 50.0 & 85 & 30.4 & 55 & $38 \cdot 2$ \\
\hline
\end{tabular}

\section{Prevalence of risk factors in any combination (Table 4)}

Table 4 shows the prevalence for both 'random' and ischaemic heart disease groups, where there is any multiple of the three risk factors. The absence of factors shows a statistically significant negative relation with ischaemic heart disease in all three age groups. For the total age range this relation is significant at $\mathrm{P}<0.00 \mathrm{I}$ level. When any one factor is present alone, there appears to be no difference in prevalence between the 'random sample' and 'ischaemic heart disease' groups. With the addition of another factor, the prevalence in the younger subjects is significantly greater in the ischaemic heart disease group $(P<0 \cdot 00$ I level). The presence of all three factors together in one subject would be expected to show a closer relation with coronary disease.

\section{Discussion}

It should be noted that our 'random sample' did contain 38 cases that we regarded as having ischaemic heart disease, and therefore any statistical relation seems to us to err on the side of caution, in associating the prevalence of the three risk factors (hyperlipidaemia, smoking, and diastolic hypertension) with coronary disease.

Our results in Table $I$ show that the prevalence of hyperlipoproteinaemia and smoking 15 or more cigarettes a day is significantly greater in the 'ischaemic heart disease' group and therefore appears to support the claim that they are risk factors, as shown by prospective studies (Dawber et al., 1962). The prevalence of diastolic hypertension is similar in the two groups, but requires further comment as it is higher in the 'random' group than would be expected from published data (Hamilton et al., 1954; Report of Inter-Society Commission for Heart Disease Resources, 1970), or from our own semibasal levels (T. B. S. Dick and M. C. Stone, 1972, unpublished data). As previously mentioned, the diastolic pressure was the first reading taken at the first interview in the lying position after a brief rest. Though this standardized procedure resulted in a relatively high prevalence of diastolic hypertension, it in no way invalidates the comparison between the groups. In addition, the conditions under which these measurements were made are similar to those encountered in the average medical outpatient clinic. The difficulty of assessing the blood pressure level as between examiners and between countries has recently been stressed (American Heart Association Monograph, 1970).

Prospective studies have shown hyperlipidaemia, hypertension, and smoking to be 'risk factors', but 
TABLE 2 Prevalence of factors when each occurs in isolation

\begin{tabular}{|c|c|c|c|c|c|c|c|c|c|c|c|c|}
\hline \multirow[t]{3}{*}{ Risk factor } & \multicolumn{4}{|c|}{$30-49$ years } & \multicolumn{4}{|c|}{$50-69$ years } & \multicolumn{4}{|c|}{$30-69$ years } \\
\hline & \multicolumn{2}{|c|}{$\begin{array}{l}\text { Random } \\
(N=145)\end{array}$} & \multicolumn{2}{|c|}{$\begin{array}{l}\text { Ischaemic } \\
\text { heart disease } \\
(N=6 I)\end{array}$} & \multicolumn{2}{|c|}{$\begin{array}{l}\text { Random } \\
\left(N=13^{8}\right)\end{array}$} & \multicolumn{2}{|c|}{$\begin{array}{l}\text { Ischaemic } \\
\text { heart disease } \\
(N=85)\end{array}$} & \multicolumn{2}{|c|}{$\begin{array}{l}\text { Random } \\
(N=283)\end{array}$} & \multicolumn{2}{|c|}{$\begin{array}{l}\text { Ischaemic } \\
\text { heart disease } \\
(N=I 46)\end{array}$} \\
\hline & No. & $\%$ & No. & $\%$ & No. & $\%$ & No. & $\%$ & No. & $\%$ & No. & $\%$ \\
\hline $\begin{array}{l}\text { Hyperlipoproteinaemia } \\
\text { Smoking } \geqslant 15 / \text { day } \\
\text { Diastolic BP } \geqslant 95 \mathrm{mmHg}\end{array}$ & $\begin{array}{r}12 \\
46 \\
8\end{array}$ & $\begin{array}{r}8 \cdot 3 \\
31 \cdot 7 \\
5 \cdot 5\end{array}$ & $\begin{array}{r}8 \\
16 \\
0\end{array}$ & $\begin{array}{l}13 \cdot 1 \\
26 \cdot 2 \\
0\end{array}$ & $\begin{array}{r}4 \\
35 \\
29\end{array}$ & $\begin{array}{r}2 \cdot 9 \\
25 \cdot 4 \\
21 \cdot 0\end{array}$ & $\begin{array}{l}10 \\
23 \\
10\end{array}$ & $\begin{array}{l}\text { II } \cdot 8 \star \\
27 \cdot 1 \\
11 \cdot 8\end{array}$ & $\begin{array}{l}16 \\
81 \\
37\end{array}$ & $\begin{array}{c}5 \cdot 7 \\
28 \cdot 6 \\
13 \cdot I^{\star}\end{array}$ & $\begin{array}{l}18 \\
39 \\
10\end{array}$ & $\begin{array}{c}12 \cdot 3^{\star} \\
26 \cdot 7 \\
6 \cdot 9\end{array}$ \\
\hline
\end{tabular}

$\star P<0.05$.

TABLE 3 Prevalence of factors as they occur in combinations of two, uninfluenced by third factor

\begin{tabular}{|c|c|c|c|c|c|c|c|c|c|c|c|c|}
\hline \multirow{3}{*}{ Risk factor } & \multicolumn{4}{|c|}{$30-49$ years } & \multicolumn{4}{|c|}{$50-69$ years } & \multicolumn{4}{|c|}{$30-69$ years } \\
\hline & \multicolumn{2}{|c|}{$\begin{array}{l}\text { Random } \\
(N=145)\end{array}$} & \multicolumn{2}{|c|}{$\begin{array}{l}\text { Ischaemic } \\
\text { heart disease } \\
(N=6 I)\end{array}$} & \multicolumn{2}{|c|}{$\begin{array}{l}\text { Random } \\
(N=138)\end{array}$} & \multicolumn{2}{|c|}{$\begin{array}{l}\text { Ischaemic } \\
\text { heart disease } \\
(N=85)\end{array}$} & \multicolumn{2}{|c|}{$\begin{array}{l}\text { Random } \\
(N=283)\end{array}$} & \multicolumn{2}{|c|}{$\begin{array}{l}\text { Ischaemic } \\
\text { heart disease } \\
(N=I 46)\end{array}$} \\
\hline & No. & $\%$ & No. & $\%$ & No. & $\%$ & No. & $\%$ & No. & $\%$ & No. & $\%$ \\
\hline $\begin{array}{l}\text { Hyperlipoproteinaemia + diastolic BP } \\
\geqslant 95 \mathrm{mmHg} \\
\text { Hyperlipoproteinaemia + smoking }\end{array}$ & 6 & $4 \cdot 1$ & 3 & $4 \cdot 9$ & 6 & $4 \cdot 4$ & 4 & $4 \cdot 7$ & 12 & $4 \cdot 2$ & 7 & $4 \cdot 8$ \\
\hline $\begin{array}{l}\geqslant 15 / \text { day } \\
\text { Diastolic BP } \geqslant 95 \mathrm{mmHg}+\text { smoking }\end{array}$ & 8 & 5.5 & 13 & $21 \cdot 3 t$ & II & $8 \cdot 0$ & 6 & $7 \cdot I$ & 19 & $6 \cdot 7$ & 19 & $13 \cdot 0^{*}$ \\
\hline$\geqslant 15 /$ day & 10 & $6 \cdot 9$ & Io & $16 \cdot 4^{\star}$ & 18 & $13 \cdot 0$ & 13 & $15 \cdot 3$ & 28 & $9 \cdot 9$ & 23 & $15 \cdot 8 \star$ \\
\hline
\end{tabular}

$\star \mathrm{P}<0.05 . \quad+\mathrm{P}<0.01$.

TABLE 4 Prevalence of risk factors (hyperlipoproteinaemia, smoking $\geqslant 15 /$ day, diastolic blood pressure $\geqslant 95$ ) occurring in any combination

\begin{tabular}{|c|c|c|c|c|c|c|c|c|c|c|c|c|}
\hline \multirow[t]{3}{*}{ Risk factors } & \multicolumn{4}{|c|}{$30-49$ years } & \multicolumn{4}{|c|}{$50-69$ years } & \multicolumn{4}{|c|}{ Total } \\
\hline & \multicolumn{2}{|c|}{$\begin{array}{l}\text { Random } \\
(N=I 45)\end{array}$} & \multicolumn{2}{|c|}{$\begin{array}{l}\text { Ischaemic heart } \\
\text { disease }(N=6 I)\end{array}$} & \multicolumn{2}{|c|}{$\begin{array}{l}\text { Random } \\
\left(N=13^{8}\right)\end{array}$} & \multicolumn{2}{|c|}{$\begin{array}{l}\text { Ischaemic heart } \\
\text { disease }(N=85)\end{array}$} & \multicolumn{2}{|c|}{$\begin{array}{l}\text { Random } \\
(N=283)\end{array}$} & \multicolumn{2}{|c|}{$\begin{array}{l}\text { Ischaemic heart } \\
\text { disease }(N=I 46)\end{array}$} \\
\hline & No. & $\%$ & No. & $\%$ & No. & $\%$ & No. & $\%$ & No. & $\%$ & No. & $\%$ \\
\hline $\begin{array}{l}\text { None } \\
\text { Any I } \\
\text { Any } 2 \\
\text { All } 3\end{array}$ & $\begin{array}{r}49 \\
66 \\
24 \\
6\end{array}$ & $\begin{array}{c}33.8+ \\
45.5 \\
16.6 \\
4.1\end{array}$ & $\begin{array}{r}6 \\
24 \\
26 \\
5\end{array}$ & $\begin{array}{c}9 \cdot 8 \\
39 \cdot 3 \\
42 \cdot 6 \ddagger \\
8 \cdot 2\end{array}$ & $\begin{array}{r}33 \\
68 \\
35 \\
2\end{array}$ & $\begin{array}{c}23 \cdot 9^{\star} \\
49 \cdot 3 \\
25 \cdot 4 \\
1.5\end{array}$ & $\begin{array}{r}9 \\
43 \\
23 \\
10\end{array}$ & $\begin{array}{l}10.6 \\
50.6 \\
27 \cdot 1 \\
11.8 \dagger\end{array}$ & $\begin{array}{r}82 \\
134 \\
59 \\
8\end{array}$ & $\begin{array}{c}29 \cdot 0 \ddagger \\
47 \cdot 3 \\
20 \cdot 9 \\
2.8\end{array}$ & $\begin{array}{l}15 \\
67 \\
49 \\
15\end{array}$ & $\begin{array}{l}10.3 \\
45.9 \\
33 \cdot 6^{\star} \\
10.3 t\end{array}$ \\
\hline
\end{tabular}

* $P<0.05 . \quad+P<0.01 . \quad \mp P<0.001$.

at Tecumseh (Epstein et al., 1965) the preliminary retrospective figures do not show a correlation with smoking, and at Busselton (Welborn et al., 1969), a retrospective study, smoking has not been found to be a factor. Our findings in respect of smoking (Table I) are similar to those of Medalie et al. (I968) and Mulcahy et al. (1969) who, also in retrospective studies, did find a significant increase in the prevalence of smoking in their 'ischaemic heart disease' group.
Consideration of the total prevalence of any one factor does ignore the possible synergistic effects of other factors occurring in association with it. Similarly, where any two unknown factors (Table 4) are combined, the significance of certain combinations of factors is concealed. For this reason in Table 2 we compared the prevalence of the three factors in both groups when they occur unassociated with either of the other two factors. The only factor which now related significantly to ischaemic heart 
disease was hyperlipoproteinaemia, but smoking in particular did not. When, however, we examined a combination of these risk factors occurring in the same subject, a greater prevalence in the 'ischaemic heart disease' group was found, except when hyperlipoproteinaemia was combined with hypertension and smoking was not present (Table 3). In this latter group there was no correlation with ischaemic heart disease; in fact the prevalence was virtually identical in the 'random' and 'ischaemic heart disease' groups for each age range. This does seem surprising when both hyperlipoproteinaemia and hypertension have been shown to be risk factors. We infer from our results that to report the prevalence of one factor without knowing the prevalence of other factors occurring in association with it can be misleading. Our findings in Table 3 suggest that smoking in the presence of hyperlipoproteinaemia or hypertension may take on a new importance which is not evident when smoking is the only factor present and is only partially evident when the total prevalence of smoking is reported.

The correction of cardinal risk factors as a preventive measure (Stamler, 197I) may be justified, but the final evaluation of this must await the result of a prospective therapeutic trial. Our results, despite defects inherent in a retrospective study, and despite rather small numbers, do suggest that a cessation of smoking could be a major preventive measure, if either of the other two cardinal risk factors, namely hyperlipidaemia or hypertension, is present in the subject.

We gratefully acknowledge research grants from the Manchester Regional Hospital Board (T.B.S.D.), the Medical Research Council (M.C.S.), and Imperial Chemical Industries Limited. We thank Joan Hampson, Mary Stone, Margaret Hodkinson, Jessie Newlands, and Kenneth Cottam for their skilled clerical and technical assistance. We are also grateful to Dr. Philip H. N. Wood for his helpful advice.

\section{References}

American Heart Association (1970). Coronary Heart Disease in 7 Countries (Monograph No. 29). Ed. by A. Keys. Circulation, New York.

Blackburn, H., Keys, A., Simonson, E., Rautaharju, P., and Punsar, S. (1960). The electrocardiogram in population studies; a classification system. Circulation, 21, 1160 .

Connerty, H. V., Brigg, A. R., and Eaton, E. H. (I96I). Simplified determination of the lipid components of blood serum. Clinical Chemistry, 7, 37.

Dawber, T. R., Kannel, W. B., Revotskie, N., and Kagan, A. (1962). Epidemiology of coronary heart disease - the
Framingham enquiry. Proceedings of the Royal Society of Medicine, 55, 265.

Doyle, J. T., Heslin, A. S., Hilleboe, H. E., and Formal, P. F. (1959). Early diagnosis of ischemic heart disease. New England fournal of Medicine, 26r, I096.

Epstein, F. H., Ostrander, L. D., Johnson, B. C., Payne, M. W., Hayner, N. S., Keller, J. B., and Francis, T. (1965). Epidemiological studies of cardiovascular disease in a total community. Annals of Internal Medicine, 62, 1170.

Friedman, G. D., Kannel, W. B., Dawber, T. R., and McNamara, P. M. (1966). Comparison of prevalence, case history and incidence data in assessing the potency of risk factors in coronary heart disease. American fournal of Epidemiology, 83, 366.

Hamilton, M., Pickering, G. W., Roberts, J. A. F., and Sowry, G. S. C. (1954). Aetiology of essential hypertension - arterial pressure in the general population. Clinical Science, 13, II.

Keys, A., Taylor, H. L., Blackburn, H., Brozek, J., Anderson, J. T., and Simonson, E. (1963). Coronary heart disease among Minnesota business and professional men followed 15 years. Circulation, 28, 381.

Medalie, J. H., Kahn, H. A., Groen, J. J., Neufeld, H. N., and Riss, E. (1968). Prevalence of ischaemic heart disease in relation to selected variables. Israel fournal of Medical Sciences, 4, 789.

Morris, J. N., Kagan, A., Pattison, D. C., Gardner, M. J., and Raffle, P. A. B. (I966). Incidence and prediction of ischaemic heart disease in London busmen. Lancet, 2, 553.

Mulcahy, R., Hickey, N., and Maurer, B. (1969). The value of retrospective surveys in the study of coronary heart disease. Public Health, 83, 176.

Report of Inter-Society Commission for Heart Disease Resources (1970). Primary prevention of the atherosclerotic diseases. Circulation, 42, p. A.89.

Stamler, J. (197I). Acute myocardial infarction - progress in primary prevention. British Heart fournal, 33, Suppl., I45.

Stamler, J., Schoenberger, J. A., Lindberg, H. A., Shekelle, R., Stoker, J. M., Epstein, M. B., DeBoer, L., Stamler, R., Restivo, R., Gray, D., and Cain, W. (1969). Detection of susceptibility to coronary disease. Bulletin of the New York Academy of Medicine, 45, I306.

Stone, M. C., Thorp, J. M., Mills, G. L., and Dick, T. B. S. (1970). Comparison of membrane filtration and nephelometry with analytical ultracentrifugation, for the quantitative analysis of low density lipoprotein fractions. Clinica Chimica Acta, 30, 809.

Stone, M. C., Thorp, J. M., Mills, G. L., and Dick, T. B. S. (1971). Diagnosis and classification of abnormal lipoprotein patterns. Clinica Chimica Acta, 31, 333.

Tibblin, G. (1970). Risk factors in coronary heart disease, thrombosis and coronary heart disease. In Advances in Cardiology (First Paavo Nurmi Symposium, Finland), Vol. 4, p. 123. Ed. by P. I. Halonen and A. Louhija. Phiebig, New York.

Welborn, T. A., Cumpston, G. N., Cullen, K. J., Curnow, D. H., McCall, M. G., and Stenhouse, N. S. (I969). The prevalence of coronary heart disease and associated factors in an Australian rural community. American fournal of Epidemiology, 89, 521.

Requests for reprints to Dr. T. B. S. Dick, Clinical Research Unit, Leigh Infirmary, The Avenue, Leigh, Lancs. 